\title{
Arsenic Uptake by Rice Is Influenced by Microbe-Mediated Arsenic Redox Changes in the Rhizosphere
}

\author{
Yan Jia, ${ }^{\dagger}{ }^{\ddagger}$ Hai Huang, ${ }^{\dagger}$ Zheng Chen, ${ }^{\dagger}$ and Yong-Guan $\mathrm{Zhu}^{*}{ }^{\dagger, \S}$ \\ ${ }^{\dagger}$ State Key Lab of Urban and Regional Ecology, Research Center for Eco-Environmental Sciences, Chinese Academy of Sciences, \\ Beijing 100085, China \\ ${ }^{\ddagger}$ Institute of Process Engineering, Chinese Academy of Sciences, Beijing 100190, China \\ ${ }^{\S}$ Key Lab of Urban Environment and Health, Institute of Urban Environment, Chinese Academy of Sciences, Xiamen 361021, China
}

\section{Supporting Information}

ABSTRACT: Arsenic (As) uptake by rice is largely determined by As speciation, which is strongly influenced by microbial activities. However, little is known about interactions between root and rhizosphere microbes, particularly on arsenic oxidation and reduction. In this study, two rice cultivars with different radial oxygen loss (ROL) ability were used to investigate the impact of microbially mediated As redox changes in the rhizosphere on As uptake. Results showed that the cultivar with higher ROL (Yangdao) had lower As uptake than that with lower ROL (Nongken). The enhancement of the rhizospheric effect on the abundance of the arsenite (As(III)) oxidase gene (aroA-like) was greater than on the arsenate $(\mathrm{As}(\mathrm{V}))$ reductase gene $(\operatorname{ars} C)$, and As $(\mathrm{V})$ respiratory reductase gene ( $\operatorname{arr} A)$, resulting in As oxidation and sequestration in the rhizosphere, particularly for cultivar Yangdao. The community of As(III)-oxidizing bacteria in the rhizosphere was dominated by $\alpha$-Proteobacteria and $\beta$-Proteobacteria and was influenced by rhizospheric effects, rice straw application, growth stage, and cultivar. Application of rice straw into the soil increased As release and accumulation into rice plants. These results highlighted that uptake of As by rice is influenced by microbial processes, especially As oxidation in the rhizosphere, and these processes are influenced by root ROL and organic matter application.

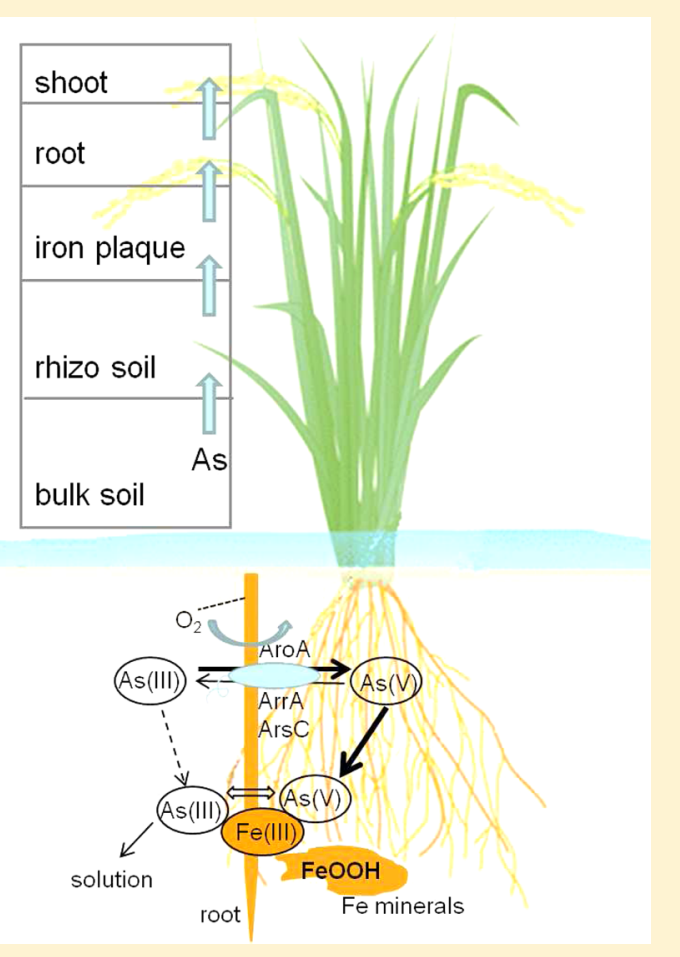

\section{INTRODUCTION}

Arsenic (As) contamination and its health impacts are widespread around the world. ${ }^{1,2}$ Large areas of paddy soils are contaminated by As due to irrigation with As-tainted groundwater, mining, and other industrial activities. Rice is particularly efficient in accumulating As, compared with other cereal crops, as a result of its anaerobic growth conditions. ${ }^{3}$ This poses potential harm to people through ingestion of rice, especially in Southeast Asia where rice is consumed as the staple food. ${ }^{4-6}$ Rhizospheric chemical processes, such as iron oxidation-reduction and iron plaque formation on root surfaces, play an important role in affecting As uptake by rice plants, and they are largely influenced by oxygen release from rice roots. ${ }^{7,8}$ The aerated rice rhizosphere and $\mathrm{O}_{2}$-releasing root surface are usually coated with iron $(\mathrm{Fe})$ and manganese $(\mathrm{Mn})$ oxides, while As is precipitated with these oxides mainly as arsenate $(\mathrm{As}(\mathrm{V}))^{8,9}$
In addition to chemical processes, As speciation and mobility in soils, sediments, and natural water systems are mainly driven by microbial transformations. ${ }^{10-12}$ Anaerobic bacteria containing the respiratory reductase (ArrA) can use $\operatorname{As}(\mathrm{V})$ as the terminal electron acceptor in respiration and conserve energy from this process. ${ }^{13}$ Another pathway for microbial $\mathrm{As}(\mathrm{V})$ reduction lies in the widespread As detoxification by $\mathrm{As}(\mathrm{V})$ reductase $(\mathrm{ArsC}) .{ }^{14,15}$ Arsenite $(\mathrm{As}(\mathrm{III}))$ is more weakly bound to most soil minerals than $\mathrm{As}(\mathrm{V})$; thus, $\mathrm{As}(\mathrm{V})$ reduction results in As release into soil solutions, especially under anaerobic conditions such as paddy soil. ${ }^{16,17}$ On the other hand, some heterotrophic as well as chemoautotrophic microorganisms are

Received: September 1, 2013

Revised: November 26, 2013

Accepted: January 2, 2014

Published: January 2, 2014 
able to oxidize $\mathrm{As}(\mathrm{III})$ to $\mathrm{As}(\mathrm{V}){ }^{18}$ Arsenite oxidation is suggested to facilitate As sequestration in metal oxides and is often used as a tool to remediate As-contaminated waters and soils. ${ }^{19}$ Arsenic-reducing and arsenic-oxidizing microbes often coexist in the environment, and their relative abundance and activity determine the geochemistry and fate of As in the environment. ${ }^{19-23}$

Although As biotransformation in the rice rhizosphere can significantly influence As uptake into plants, little has been done on microbial reduction and oxidation of As in the rhizosphere and how it influences As uptake into rice plants. The rice rhizosphere is characterized by strong oxygenation through root radical oxygen loss (ROL) as compared to the bulk soil in relation to soil properties, microbial composition, and activities. ${ }^{24,25}$ Moreover, mucigel, polysaccarides, amino acids, and organic acids released to the rhizosphere from the roots promote microbial abundance and alter community structures. ${ }^{26}$ In fact, the biogeochemical cycling within the rice rhizosphere is so intense and complex that this environment is usually studied as an independent compartment. ${ }^{25}$ Arsenic biotransformation in the rice rhizosphere significantly influences As interaction with $\mathrm{Fe}$ and $\mathrm{Mn}$ minerals and its bioavailability to the plants. Therefore, the aims of this study were to investigate the microbial oxidation and reduction of As in the rhizosphere of two rice cultivars with different root ROL ability and its influence on As bioavailability and uptake to the plants. Furthermore, rice straw is usually returned to paddy fields; therefore, the influence of rice straw incorporation on As transformation in paddy soil was also studied.

\section{MATERIALS AND METHODS}

Rice Cultivation. Soil for the pot experiment was collected from a paddy field in Qiyang city (Hunan province, China). Its As concentration was $56.0 \mathrm{mg} \mathrm{kg}^{-1}$. Four kilograms of soil were placed into each pot (16 pots), $400 \mathrm{~g}$ of which was placed in a nylon mesh $(24 \mu \mathrm{m})$ bag (height of $12 \mathrm{~cm}$; diameter of $8 \mathrm{~cm}$ ) to create a central compartment (rhizosphere), while the outside compartment (bulk soil) was free of roots. ${ }^{27}$ Rice straw was cut into $1 \mathrm{~cm}$ pieces and added to the soil at $6.25 \mathrm{~g} \mathrm{~kg}^{-1}$ soil $\left(25 \mathrm{~g} \mathrm{pot}^{-1}\right)$ in eight of the pots. One pregerminated rice seedling of Yangdao 6 (YD) or Nongken 57 (NK) was then transplanted into the central compartment, which was then flooded with water to $3 \mathrm{~cm}$ during rice growth. The four treatments were (1) YD growth without rice straw addition, (2) YD growth with rice straw addition, (3) NK growth without rice straw addition, and (4) NK growth with rice straw addition, with four replicates. Rice cultivar YD was previously shown to be significantly higher in root ROL than cultivar $\mathrm{NK}^{28}$ A rhizosampler (Rhizon Soil Moisture Samplers, Rhizosphere Research Products, The Netherlands) with a nylon filter was embed into the soil of both compartments.

Soil redox potential (Eh) during the experiment was measured as reported. ${ }^{29}$ Soil solution was extracted $0,3,15$, 30,60 , and 100 days after rice planting, passed through $0.45 \mu \mathrm{m}$ filters, and then maintained at $1 \% \mathrm{HNO}_{3}$ for further determination of As speciation by HPLC-ICP-MS (Agilent 1200 and Agilent 7500; Agilent Technology, U.S.A.), and total As concentration by ICP-MS (Agilent 7500; Agilent Technology, U.S.A.). ${ }^{23}$ The rhizosphere soils and bulk soils were sampled at the tillering stage ( 30 days) and the beginning of the heading stage (100 days) and then used for DNA extraction.

Plant Analysis. Shoots and roots were harvested at day 100 and thoroughly washed with distilled water. Half of each root sample was incubated in DCB (dithionite-citrate-bicarbonate) solution for extraction of iron plaque on the roots surface, $^{30}$ and the other half was used for extraction of total microbial DNA on the root. Concentrations of As, Fe, Mn, and $\mathrm{P}$ in the extraction solution were determined by ICP-OES (Optima 2000 DV; Perkin-Elmer, U.S.A.) or ICP-MS. After $\mathrm{DCB}$ extraction, roots and shoots were freeze-dried, ground to powder, and stored in a $-80{ }^{\circ} \mathrm{C}$ refrigerator. Total As concentration in shoots and $\mathrm{DCB}$ extracted roots were digested in $\mathrm{HNO}_{3}$ using a microwave digestion system (MARS, CEM Microwave Technology Ltd., U.S.A.) and determined using ICP-MS. $^{29}$

Soil DNA Extraction. Total microbial DNA was isolated from roots, rhizosphere soil, and bulk soil samples from the pot experiment using a FastDNA SPIN Kit for Soil (MP Biomedicals, U.S.A.) and the FastPrep Instrument (MP Biomedicals, U.S.A.) following the manufacturer's instructions.

Quantification of 16S rDNA, aroA-like, arrA, and arsC Gene Copy Numbers. Soil DNA was conducted in real-time quantitative PCR (iQ5 Thermocycler; BioRad, U.S.A.) to quantify $16 \mathrm{~S}$ rDNA, arrA gene, and $\operatorname{ars} C$ gene abundance in each sample. For quantification of the $\operatorname{aro} A$-like, $\operatorname{ars} C$, and $\operatorname{arr} A$ genes, primers of AroAdeg1F/AroAdeg1R and AroAdeg2F/ AroAdeg2R, ${ }^{18}$ amlt-42-f/amlt-376-r and smrc-42-f/smrc-376$\mathrm{r}^{31}$ and HAArrA-D1F/HAArrA-G2 ${ }^{32}$ were used, respectively. Details are in the Supporting Information.

Construction of the aroA-like, arrA, and arsC Clone Library. DNA from the rhizosphere soil and rice roots (Yangdao growth without rice straw addition, each with four replicates) in the pot experiment were used for the construction of $\operatorname{aroA}$-like, arrA, and $\operatorname{ars} C$ clone libraries. The cloned sequences were submitted to the NCBI database from JX489044-JX489133 (arrA gene from JX489044-JX489050, aroA-like gene from JX489051-JX489101, and ars C gene from JX489102-JX489133).

Terminal Restriction Fragment Length Polymorphism (T-RFLP) Analysis of aroA-like Gene. PCR amplification of aroA-like gene was conducted with each forward primer labeled by 6-carboxyfluorescein (FAM). The labeled PCR products were gel-purified with the Wizard SV Gel and PCR Clean-Up System and then digested by the restriction enzyme TaqI (Takara, Japan) at $37{ }^{\circ} \mathrm{C}$ for $3 \mathrm{~h}$. Digestion products were determined with 3130XL Genetic Analyzer (Applied Biosystems, U.S.A.). Relative abundances of each individual terminal restriction fragments (T-RFs) were calculated based on peak areas in relation to total peak area. Peaks that occurred in at least three replicates and with a percentage $>2 \%$ were listed.

Statistical Analysis. Effects of rice cultivar, rhizosphere/ bulk soil, rice growth stage, and rice straw application on abundance and composition of aroA-like genes were evaluated using canonical correspondence analysis (CCA) in CANOCO for Windows 4.54. Abundances of functional genes were subjected to ANOVA in SPSS 13.0, and $P<0.05$ was considered to be statistically significant.

\section{RESULTS}

Arsenic in Plants and Iron Plaque. Arsenic concentrations in roots were significantly higher than those in shoots and were significantly higher in shoots of cultivar NK than in cultivar YD (Table 1). Rice straw addition into the soil significantly increased As concentrations in roots of both 
Table 1. Arsenic Concentration in Shoots and Roots and Translocation Factor (TF) of Yangdao and Nongken Grown with or without Rice Straw Application into Paddy Soil ${ }^{a}$

$\begin{array}{ccccc}\text { rice } & \text { rice } & \text { straw } & \begin{array}{c}\text { root (without } \\ \text { iron plaque) } \\ \mathrm{mg} \mathrm{kg}^{-1}\end{array} & \begin{array}{c}\text { shoot } \mathrm{mg} \mathrm{kg}^{-1} \\ \text { translocation factor } \\ \text { (TF) }\end{array} \\ \text { Yangdao } & \text { no } & 9.2 \pm 0.5 \mathrm{~b} & 223 \pm 17 \mathrm{~b} & 0.042 \pm 0.004 \mathrm{ab} \\ & \text { yes } & 10.3 \pm 0.8 \mathrm{~b} & 305 \pm 47 \mathrm{ab} & 0.037 \pm 0.009 \mathrm{~b} \\ \text { Nongken } & \text { no } & 15.0 \pm 2.2 \mathrm{a} & 294 \pm 37 \mathrm{ab} & 0.056 \pm 0.005 \mathrm{a} \\ & \text { yes } & 18.8 \pm 1.2 \mathrm{a} & 351 \pm 32 \mathrm{a} & 0.056 \pm 0.009 \mathrm{a}\end{array}$

${ }^{a}$ Data are mean \pm SE $(n=4)$. Different letters mean significant differences of As concentration and translocation factor between the treatments $(P<0.05)$.

cultivars but not in shoots. The translocation factor (TF) was not significantly different between the four treatments.

Concentrations of $\mathrm{Fe}$ and $\mathrm{Mn}$ in iron plaque of cultivar YD were higher than that of cultivar NK regardless of straw addition (Table 2). There were no significant differences in As concentrations on iron plaque between treatments.

Arsenic in Soil Solutions. The detected As species in soil solution were $\mathrm{As}(\mathrm{III})$ and $\mathrm{As}(\mathrm{V})$ (Figure 1), and also a trace amount of DMAs(V) and MMAs(V) (data not shown); As(III) accounted for $76-89 \%$ of the total As in soil solution (Figure la, b). Irrespective of treatments, concentrations of total As and As(III) in bulk and rhizosphere soil solutions increased greatly in the first 15 days after flooding and then decreased to a relatively steady state level. Total As concentrations in rhizosphere soil solutions were lower than those in bulk soil solutions, irrespective of treatments (Figure 1e, f) by $16.8 \%$ and $13.5 \%$ on average for cultivar YD and NK, respectively. The addition of rice straw increased As(III) and total As concentrations in the rhizosphere and bulk soil solutions of both cultivars by $36.5 \%$ and $27.0 \%$ on average for cultivar YD and NK, respectively.

16S rDNA and $\operatorname{ars} C$, $\operatorname{arrA}$, and aroA-like Gene Abundances. Quantitative PCR assays were conducted to quantify abundances of genes related to As transformation in the rhizosphere and bulk soil. Copy numbers of $16 \mathrm{~S}$ rDNA and the $\operatorname{ars} C$, $\operatorname{arr} A$, and aroA-like genes were influenced by the rhizospheric effect, rice cultivar, straw addition, and growth stage (Figure 2; Table S2, Supporting Information). Abundance of $\operatorname{arr} A$ and $\operatorname{ars} C$ genes in the paddy soil were $10^{7}$ and $10^{7}-10^{8}$ copies $\mathrm{g}^{-1}$ dry soil, respectively, and the aroA-like gene was usually higher than $10^{8}$ copies $\mathrm{g}^{-1}$ dry soil (Figure 2 ). Copies of $16 \mathrm{~S} \mathrm{rDNA}$ and the aroA-like gene were generally higher in the rhizosphere soil of cultivar YD than NK, regardless of treatments (Figure 2; Table S2, Supporting Information). Overall, bacterial abundance (16S rDNA) was higher in rhizosphere soil by $59.2 \%$ on average compared to bulk soil, while the copy numbers of the $\operatorname{ars} C$, $\operatorname{arr} A$, and $\operatorname{aro} A$-like genes were increased by $50.8 \%, 20.8 \%$, and $120.9 \%$ on average, respectively. This showed more enhancement in microbial abundances of As(III) oxidation (aroA-like gene) and less enhancement in microbial abundances of $\mathrm{As}(\mathrm{V})$ reduction ( $\operatorname{ars} C$ and $\operatorname{arr} A$ genes). Rice straw addition into the paddy soil significantly elevated the abundances of $16 \mathrm{~S}$ rDNA and the $\operatorname{ars} C$, $\operatorname{arr} A$, and aroA-like genes in both rhizosphere and bulk soil in all treatments (Figure 2; Table S2, Supporting Information). Relative gene abundances $(\Delta=\operatorname{aro} A-\operatorname{ars} C-$ $\operatorname{arr} A$, to indicate the relative As oxidation potential) and concentrations of dissolved As in soil solution were in a linear relationship $(R=0.300, P<0.05)$ (Figure 3 ).

Arsenate-Reducing Microbes in Rice Rhizosphere. Diversity of microbes in the rice rhizosphere associated with As reduction is shown in Figures $\mathrm{S} 1$ and $\mathrm{S} 2$ of the Supporting Information. Analysis of the 50 ars $C$ cloned sequences from rhizosphere soil and rice roots allowed the identification of 35 unique OTUs based on a 97\% cutoff (Figure S1, Supporting Information). The main classes of these sequences belonged to $\alpha$-, $\beta$-, and $\gamma$-Proteobacteria, including Enterobacteriales, Rhizobiales, Sphingomonadales, Burkholderiales. and Xanthomonadales. Some of these are branched to the common rhizospheric bacteria, such as Rhizobiales and Burkholderiales. Distribution of the taxonomic groups of ars $C$ from rhizosphere soil and rice roots were among most of the detected groups but were gathered in different small groups revealing the similarities and differences of microbes on rice roots and in rhizosphere soil. Fourteen different arrA clones were amplified from the rhizosphere soil but not from the roots. Because of the scarcity of the already known arrA sequences in the NCBI database, a detailed classification of these clones to an identified microbial species was not possible. These amplified $\operatorname{arr} A$ sequences in the rhizosphere soil were aligned to previously reported partial arrA sequences amplified from anaerobic aquifer sediments, bay sediments, river basins, and biofilm reactors (Figure S2, Supporting Information).

Arsenite-Oxidizing Microbes in Rice Rhizosphere. A clone library was established to show the major microbial taxa responsible for As oxidation in the rhizosphere. Analysis of the 65 aroA-like sequences from rhizosphere soil and rice roots allowed the identification of 53 unique OTUs based on a $97 \%$ cutoff (Figure S3, Supporting Information). The microbes were mainly Rhizobiales and Burkholderiales in $\alpha$-Proteobacteria and $\beta$-Proteobacteria, including Phyllobacteriaceae, Bradyrhizobiaceae, Methylobacteriaceae, Rhizobiaceae, Bulkholderiaceae, and Comamonadaceae, and also seven unknown clusters, mainly rhizospheric microbes. Terminal restriction fragment length polymorphism (T-RFLP) analysis was conducted to reveal the differences in aroA-like microbial communities with different treatments (Figure S4, Supporting Information). Ten T-RFs $(50,81,89,110,131,166,221,321,348$, and $378 \mathrm{bp})$ were

Table 2. Iron Plaque Composition on Roots of Yangdao and Nongken Grown with or without Rice Straw Application in Paddy Soil $^{a}$

$\begin{array}{cccccc} & \text { rice straw } & \mathrm{Fe} \mathrm{g} \mathrm{kg}^{-1} & \mathrm{Mn} \mathrm{g} \mathrm{kg}^{-1} & \mathrm{P} \mathrm{g} \mathrm{kg}^{-1} & \mathrm{As} \mathrm{g} \mathrm{kg}^{-1} \\ \text { Yangdao } & \text { no } & 48.3 \pm 2.6 \mathrm{a} & 0.319 \pm 0.010 \mathrm{a} & 2.88 \pm 0.14 \mathrm{~b} & 0.462 \pm 0.021 \mathrm{a} \\ & \text { yes } & 44.2 \pm 0.9 \mathrm{ab} & 0.325 \pm 0.021 \mathrm{a} & 2.49 \pm 0.29 \mathrm{bc} & 0.430 \pm 0.027 \mathrm{a} \\ \text { Nongken } & \text { no } & 42.1 \pm 2.2 \mathrm{~b} & 0.263 \pm 0.044 \mathrm{~b} & 3.58 \pm 0.231 \mathrm{a} & 0.463 \pm 0.033 \mathrm{a} \\ & \text { yes } & 35.7 \pm 3.4 \mathrm{c} & 0.258 \pm 0.010 \mathrm{~b} & 2.35 \pm 0.13 \mathrm{c} & 0.469 \pm 0.019 \mathrm{a}\end{array}$

${ }^{a}$ Data are mean $\pm \mathrm{SE}(n=4)$. Different letters mean significant differences of $\mathrm{Fe}, \mathrm{Mn}, \mathrm{P}$, and As concentration between the treatments $(P<0.05)$. Linear relationship of As and $\mathrm{Fe}$ is $y=0.0094 x+157.7, R^{2}=0.885$. 


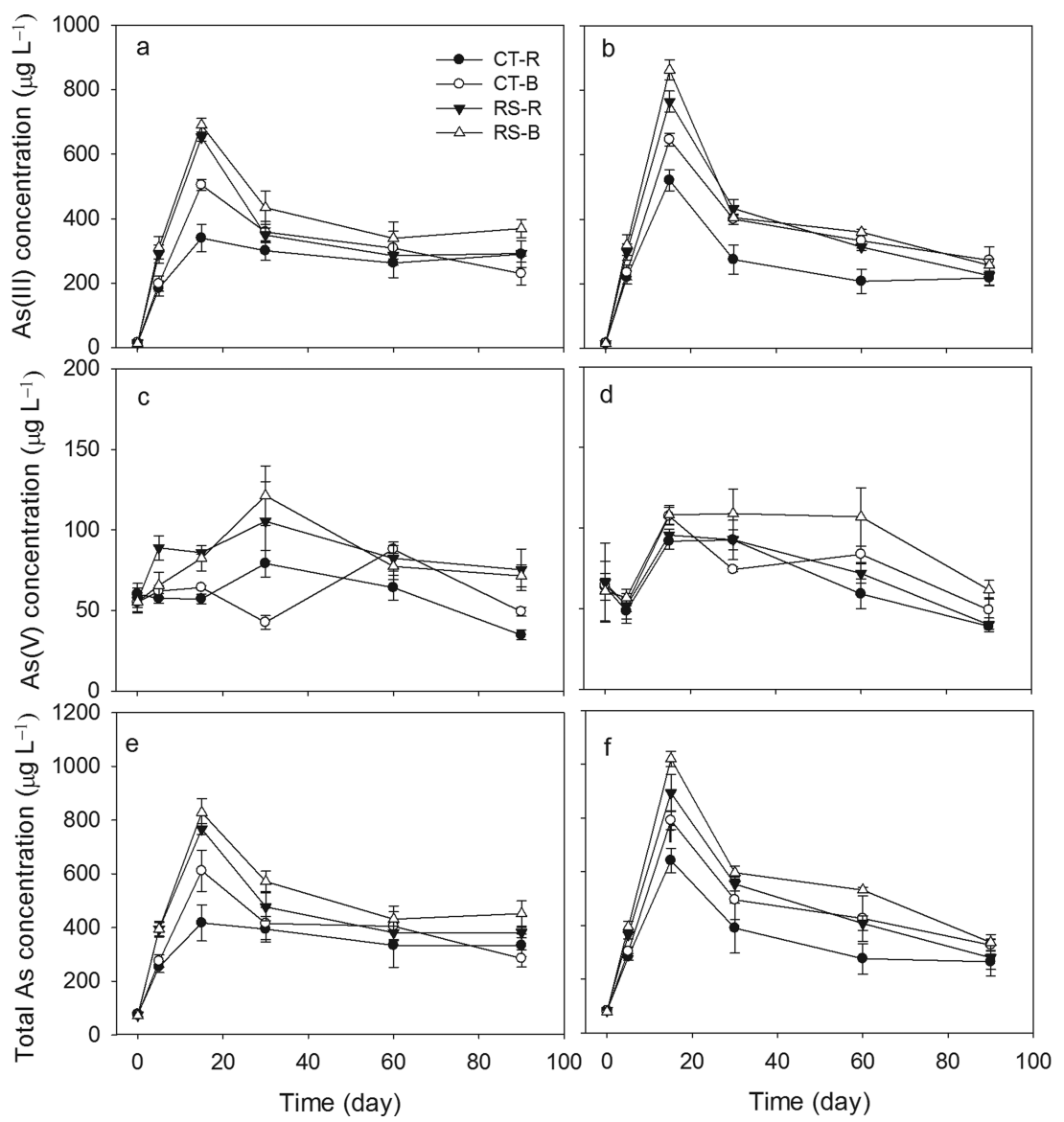

Figure 1. Arsenite (a, b), arsenate (c, d), and total As (e, f) concentration in the soil solutions of rhizosphere and bulk soils of Yangdao and Nongken with or without rice straw application in tillering and heading stages. Bars represent standard errors $(n=4)$. CT-R, rhizosphere soil without rice straw application; CT-B, bulk soil without rice straw application; RS-R, rhizosphere soil with rice straw application; and RS-B, bulk soil with rice straw application.

detected in T-RLFP profiles in almost all the treatments. These T-RFs and their relative abundances were similar to in vivo digestion of the cloned sequences in the phylogenetic tree (Figure S3, Supporting Information). The most abundant T-RF $81 \mathrm{bp}$ mainly branched to cluster 7 in the phylogenetic tree (Figure S3, Supporting Information). The percentages of $50 \mathrm{bp}$ and $81 \mathrm{bp}$ T-RF were generally elevated, while the percentages of $131 \mathrm{bp}$ and $221 \mathrm{bp}$ T-RF were lower in the rhizosphere soil than those in the bulk soil. An obvious example was that the clones with an in vivo T-RF of 50, 81, 110, and 321 bp given in the phylogenetic tree were mainly from the rice roots (Figure S3, Supporting Information), suggesting root enhanced microbes.

The canonical correspondence analysis (CCA) reflected the relative contribution of environmental factors (rhizosphere/ bulk soil, rice cultivar, growth stage, rice straw application) to the T-RLFP profile of the aroA-like gene (Figure 4). Global Monte Carlo permutation tests demonstrated that both the first axis and all axes combined explained a significant amount of the variability in the aroA-like community structure $(P<0.01)$. The first and second axis accounted for 55.5\% $(P<0.01)$ and $23.8 \%$ $(P<0.01)$ of the total variance, respectively. Rhizospheric effects explained most variation in the microbial community and negatively correlated with the first axis. Growth stage and rice straw application also explained parts of the community variation, followed by rice cultivar. The correlation of T-RF profiles with rhizospheric effects reflected by CCA also agreed with the pattern of the community profile in Figure S4 of the Supporting Information, with an increase in percentage of 50, 81, 110, $321 \mathrm{bp} \mathrm{T-RF} \mathrm{and} \mathrm{a} \mathrm{decrease} \mathrm{in} \mathrm{other} \mathrm{T-RFs} \mathrm{in} \mathrm{the}$ rhizosphere soil compared to those in the bulk soil (Figure 4).

\section{DISCUSSION}

The present study revealed that rice uptake of As was modulated by the dynamics of microbial functional groups/ genes related to As reduction and oxidation in the rhizosphere. Environmental factors influenced the abundance and community of As-transforming bacteria thus determined As behavior in the paddy soil. Functional genes responsible for As reduction and oxidation in rhizosphere soil, such as $\operatorname{arr} A, \operatorname{ars} C$, and $\operatorname{aro} A$ like genes, were altered in comparison with bulk soil, of which the abundance of As(III)-oxidizing microbes (possess aroA-like gene) were increased more as compared to bacteria abundance (16S rDNA) in the rice rhizosphere (Figure 2). Microbial As reduction and oxidation together determined the As speciation and abundance in the soil solution, shown by the relationship between relative gene abundances and concentrations of dissolved As in soil solution (Figure 3). Microbial oxidation of $\mathrm{As}(\mathrm{III})$ to $\mathrm{As}(\mathrm{V})$ was enhanced in the rhizosphere and then sequestered on $\mathrm{Fe} / \mathrm{Mn}$ hydroxide/oxyhydroxide precipitate in rhizosphere soil and on rice roots (Table 2), which reduced As bioavailability and uptake into rice plants.

Arsenic bioavailability in anaerobic paddy soil is usually high due to microbial reduction of iron oxyhydroxides and As. ${ }^{17,33}$ 


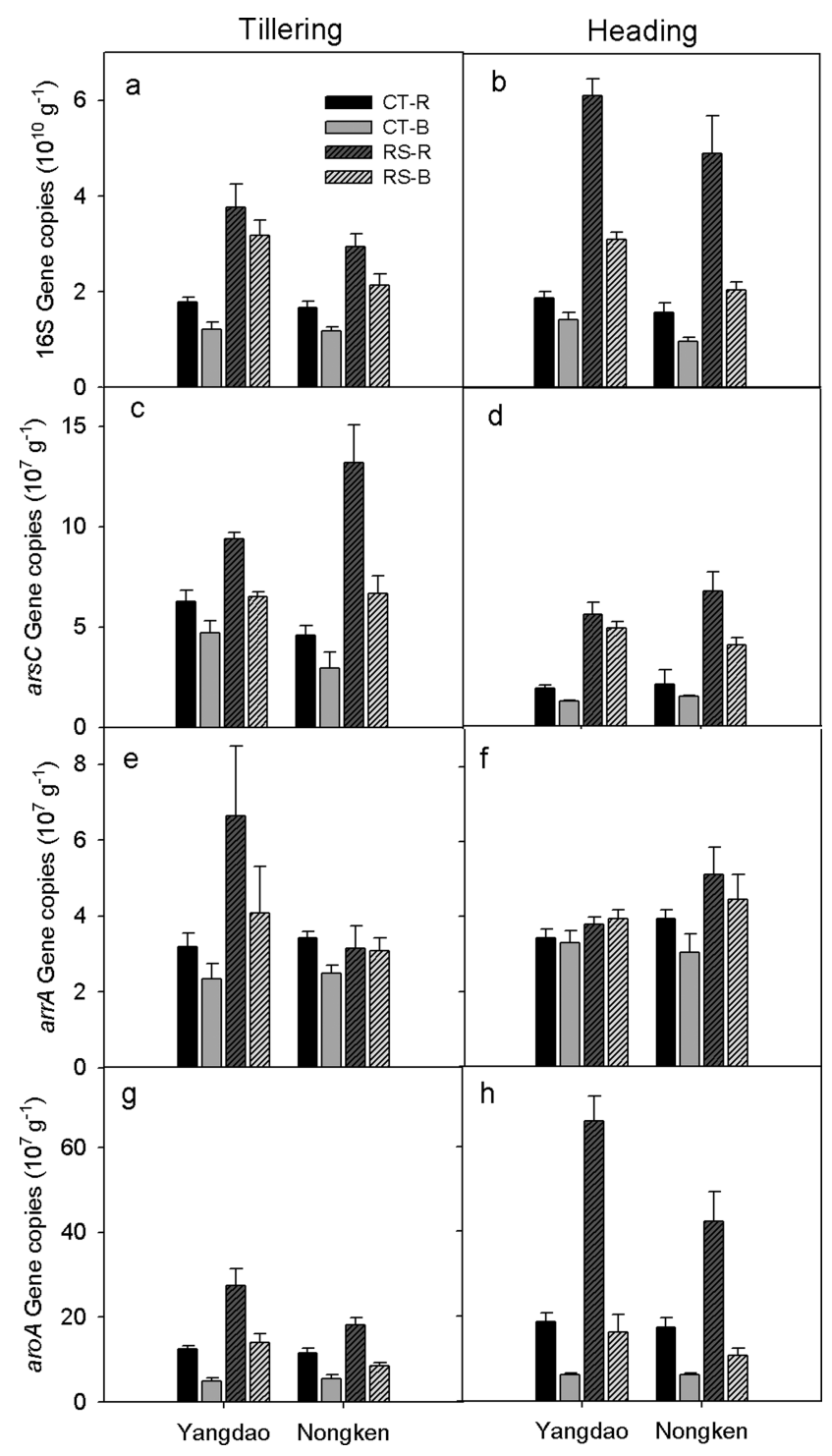

Figure 2. Copy numbers of $16 \mathrm{~S} \operatorname{rDNA}(\mathrm{a}, \mathrm{b})$, arsC gene (c, d), arrA gene $(\mathrm{e}, \mathrm{f})$, and $\operatorname{aro} A$-like gene $(\mathrm{g}, \mathrm{h})$ in the rhizosphere and bulk soils of Yangdao and Nongken with or without rice straw application in tillering and heading stages. Bars represent standard errors $(n=4)$.

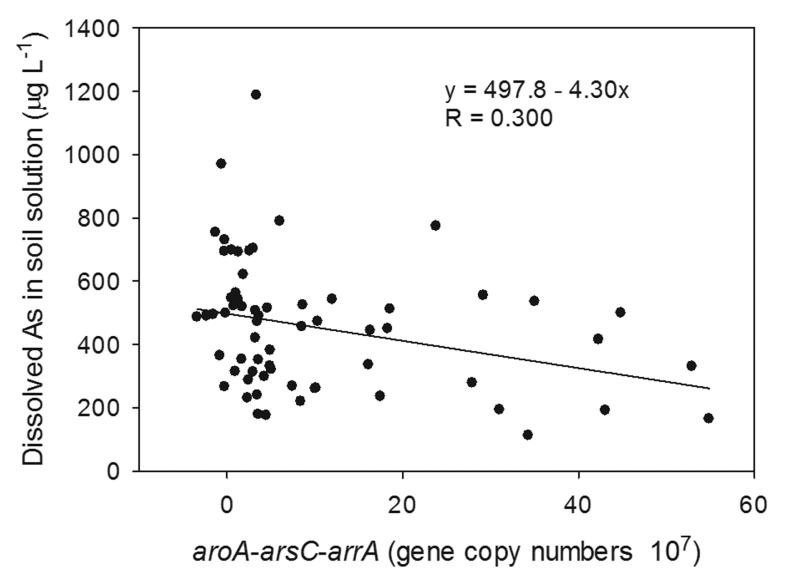

Figure 3. Relationship of relative gene abundances $(\Delta=\operatorname{aro} A-\operatorname{ars} C$ $-\operatorname{arr} A)$ and concentration of dissolved As in soil solution. $P<0.05$.

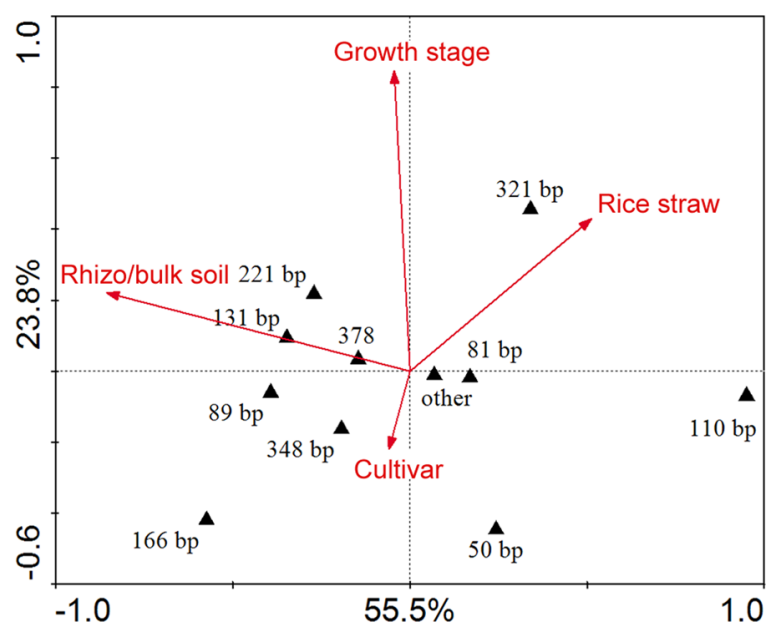

Figure 4. Canonical correspondence analysis of aroA-like gene terminal restriction fragment length polymorphism (T-RLFP) profiles. Plots show the relationship between As(III)-oxidizing bacteria communities and environmental factors (rhizosphere/bulk soil, cultivar, growth stage, and rice straw application). Arrows indicate the direction and magnitude of each factor associated with bacterial communities.

Some As(V)-respiring bacteria have been isolated from sediments, alkaline and saline lakes, and hot springs, ${ }^{13,34,35}$ respiring $A s(V)$ under the anaerobic condition to gain energy. These amplified arrA clones from rhizosphere soil were branched to $\operatorname{arr} A$ sequences amplified from aquifer sediments, bay sediments, river basins, and biofilm reactors. ${ }^{36,37}$ The dissimilatory $\mathrm{As}(\mathrm{V})$ reduction gene $\operatorname{arrA}$ was more likely present among the anaerobic microbes, which limited its wide presence in the rice rhizosphere. Instead, the $\mathrm{As}(\mathrm{V})$ detoxification reductase gene $\operatorname{ars} C$ is more widespread than the $\operatorname{arr} A$ gene among both anaerobic and aerobic microbes. ${ }^{11,38}$ In this study, the abundance and diversity of the $\operatorname{ars} C$ gene was higher than those of the $\operatorname{arrA}$ gene in rhizosphere soil (Figure 2; Figure S2, Supporting Information), showing its importance in As reduction. Some of the microbes were typically rhizospheric microbes, such as Rhizobiales and Burkholderials. It has been previously suggested that ars C contributed to $\mathrm{As}(\mathrm{V})$ reduction and mobility under highly aerobic conditions of limed mine tailings. ${ }^{39}$

Abundance of the aroA-like gene in rhizosphere soil was one fold higher than that in the bulk soil, indicating elevated microbial As oxidation in the rice rhizosphere (Figure 2). Under sterilized conditions, As(III) was stable under both aerobic and anaerobic conditions, while oxygen alone barely oxidized As(III), ${ }^{21}$ suggesting the importance of microbially mediated As(III) oxidation. Arsenic sequestered in the rice rhizosphere was mainly in the form of $\mathrm{As}(\mathrm{V})$ by Fe hydroxide/ oxyhydroxide in root iron plaque and soil around the root. ${ }^{8,40,41}$ Therefore, the increased microbial As(III) oxidation may contribute to such As sequestration in the rice rhizosphere. The rhizo-bag method was used to define the rhizosphere soil in this study. The rhizosphere may be more limited to millimeters around roots and more severe influence by roots would be expected. ${ }^{24}$ The mass-flow of As from bulk soil during water assimilation into rice roots, together with the fast efflux of As(III) from roots, ${ }^{42}$ also contributed to the replenishment of dissolved As to the rice rhizosphere. Thus, the actual effects of As oxidation and sequestration in the rice rhizosphere are likely more profound than the observed $(16.8 \%$ and $13.5 \%$ lower 
than in bulk soil solution for YD and NK, respectively), shown by the fact that As accumulation on the root surface alone was higher than that accumulated in the whole plant. The major groups of As oxidizing bacteria were $\alpha$-Proteobacteria and $\beta$ Proteobacteria in the rhizosphere and were mainly rhizospheric microbes (Figure S3, Supporting Information), while undefined cluster 1 and cluster 7 was enhanced on roots (Figure S3, Supporting Information). The diversity of the aroA-like gene revealed in this study is similar to what has been observed in many other diverse environments, such as mining-impacted soils and As-contaminated lake sediments; ${ }^{18,43,44}$ whereas in geothermal environments, aroA-like microbes were dominated by Aquificae. ${ }^{18,45}$ Arsenic oxidation and reduction $(\mathrm{ArsC})$ share some microbial groups, such as Bradyrhizobiaceae and Rhizobiaceae, and also some different groups (Figures S1 and S3, Supporting Information).

The rhizosphere had the greatest influence on the bacterial community in the soil, followed by rice straw application, rice growth stage, and rice cultivar (Figure 4; Figure S4, Supporting Information). The rice rhizosphere is the crucial microenvironment influencing As bioavailability and uptake into rice plants. ${ }^{46}$ The rice rhizosphere was different in soil physicalchemical properties, shown by the elevated $\mathrm{Eh}$ and the lower soil pH (Figures S5 and S6, Supporting Information). Arsenicoxidizing microbes were usually aerobic and thus were more likely to be elevated in the rice rhizosphere. The higher abundance of the aroA-like gene in the rhizosphere of cultivar YD than NK (Figure 2; Table S2, Supporting Information) was likely due to greater $\mathrm{O}_{2}$ release. Total As sequestered on iron plaque (As concentration $\times$ root weight) of cultivar YD was higher than cultivar NK, and this could contribute to the lower As concentration in cultivar YD. Previous studies have suggested that rice genotypes with higher ROL accumulate lower overall As. ${ }^{4748}$ However, these studies did not take into consideration the influence of ROL on microbial As transformation; whereas microbial As oxidation also contributes to As retention around the roots. High root ROL would be a useful trait for selecting genotypes to grow in As contaminated areas. Furthermore, the input of rice straw into paddy soil significantly increased the microbial activity and increased As release to the soil solution and uptake into rice plants. Microbial degradation of organic matter usually couples with the reduction of $\mathrm{Fe}(\mathrm{III})$ minerals and $\mathrm{As}(\mathrm{V})$, which together enhances As release to the soil solution and elevates As bioavailability. ${ }^{23,29}$ Therefore, it was suggested that organic matter input into As-impacted paddy soils should be handled with care.

In conclusion, microbial As transformation in the rice rhizosphere has been overlooked in previous research when considering As bioavailability and its uptake into rice plants. As(III)-oxidizing and As(V)-reducing bacteria coexist in the rice rhizosphere, and their relative activities determine the As dynamic in the rhizosphere soil solution. In the rice rhizosphere, the abundance of As-oxidizing bacteria was more elevated than the As-reducing bacteria in comparison with their abundances in bulk soil. Arsenic oxidation under the activity of As-oxidizing microbes, together with the oxic soil condition in the rice rhizosphere, resulted in As sequestration around rice roots and in rhizosphere soil, which limited As uptake into rice plants. To reduce the As accumulation in rice plants, rice cultivars with high oxygen loss ability are preferred, while organic matter input into As-impacted paddy soil should be handled with care.

\section{ASSOCIATED CONTENT}

\section{Supporting Information}

Figures S1-S3: Neighbor-join phylogenetic tree of representative $\operatorname{ars} C, \operatorname{arr} A$, and $\operatorname{aro} A$-like sequences. Figure S4: Community structure of aroA-like gene in the rhizosphere and bulk soils. Figure S5: Redox potential (Eh) of the rhizosphere and bulk soils. Figure S6: $\mathrm{pH}$ of the rhizosphere and bulk soils after rice harvest. Table S1: Efficiency of the Q-PCR test for $16 \mathrm{~S}$ rRNA, aroA-like, ars $C$, and arrA gene. Table S2: ANOVA test for copy number of $16 \mathrm{~s}$ rRNA, aroA-like, ars $C$, and $\operatorname{arrA}$ gene. Table S3: Plant biomass of Yangdao and Nongken. This material is available free of charge via the Internet at http://pubs.acs.org.

\section{AUTHOR INFORMATION}

\section{Corresponding Author}

*Phone: 86-592-6190997. Fax: 86-592-6190997. E-mail: ygzhu@rcees.ac.cn.

\section{Notes}

The authors declare no competing financial interest.

\section{ACKNOWLEDGMENTS}

This work is financially supported by the Natural Science Foundation of China (41090284 and 41330853) and Chinese Academy of Sciences (KZCX2-EW-QN410).

\section{REFERENCES}

(1) Fendorf, S.; Michael, H. A.; van Geen, A. Spatial and temporal variations of groundwater arsenic in South and Southeast Asia. Science 2010, 328 (5982), 1123-1127.

(2) Karagas, M. R. Arsenic-related mortality in Bangladesh. Lancet 2010, 376 (9737), 213.

(3) Su, Y. H.; McGrath, S. P.; Zhao, F. J. Rice is more efficient in arsenite uptake and translocation than wheat and barley. Plant Soil 2010, 328 (1-2), 27-34.

(4) Mondal, D.; Polya, D. A. Rice is a major exposure route for arsenic in Chakdaha block, Nadia district, West Bengal, India: A probabilistic risk assessment. Appl. Geochem. 2008, 23 (11), 29872998.

(5) Zhu, Y. G.; Williams, P. N.; Meharg, A. A. Exposure to inorganic arsenic from rice: A global health issue? Environ. Pollut. 2008, 154 (2), 169-171.

(6) Li, G.; Sun, G. X.; Williams, P. N.; Nunes, L.; Zhu, Y. G. Inorganic arsenic in Chinese food and its cancer risk. Environ. Int. 2011, 37 (7), 1219-1225.

(7) Chen, Z.; Zhu, Y. G.; Liu, W. J.; Meharg, A. A. Direct evidence showing the effect of root surface iron plaque on arsenite and arsenate uptake into rice (Oryza sativa) roots. New Phytol. 2005, 165 (1), 9197.

(8) Liu, W. J.; Zhu, Y. G.; Hu, Y.; Williams, P. N.; Gault, A. G.; Meharg, A. A.; Charnock, J. M.; Smith, F. A. Arsenic sequestration in iron plaque, its accumulation and speciation in mature rice plants (Oryza sativa L.). Environ. Sci. Technol. 2006, 40 (18), 5730-5736.

(9) Frommer, J.; Voegelin, A.; Dittmar, J.; Marcus, M. A.; Kretzschmar, R. Biogeochemical processes and arsenic enrichment around rice roots in paddy soil: Results from micro-focused X-ray spectroscopy. Eur. J. Soil Sci. 2011, 62 (2), 305-317.

(10) Smith, A. H.; Lingas, E. O.; Rahman, M. Contamination of drinking-water by arsenic in Bangladesh: A public health emergency. Bull. W. H. O. 2000, 78 (9), 1093-1103.

(11) Silver, S.; Phung, L. T. Genes and enzymes involved in bacterial oxidation and reduction of inorganic arsenic. Appl. Environ. Microbiol. 2005, 71 (2), 599-608.

(12) Páez-Espino, D.; Tamames, J.; de Lorenzo, V.; Cánovas, D. Microbial responses to environmental arsenic. Biometals 2009, 22 (1), 117-130. 
(13) Malasarn, D.; Saltikov, C. W.; Campbell, K. M.; Santini, J. M.; Hering, J. G.; Newman, D. K. arrA is a reliable marker for $\mathrm{As}(\mathrm{V})$ respiration. Science 2004, 306 (5695), 455-455.

(14) Jackson, C.; Dugas, S. Phylogenetic analysis of bacterial and archaeal ars $C$ gene sequences suggests an ancient, common origin for arsenate reductase. BMC Evol. Biol. 2003, 3 (1), 18.

(15) Villegas-Torres, M. F.; Bedoya-Reina, O. C.; Salazar, C.; VivesFlorez, M. J.; Dussan, J. Horizontal ars $C$ gene transfer among microorganisms isolated from arsenic polluted soil. Int. Biodeter. Biodegr. 2011, 65 (1), 147-152.

(16) Dixit, S.; Hering, J. G. Comparison of arsenic (V) and arsenic (III) sorption onto iron oxide minerals: Implications for arsenic mobility. Environ. Sci. Technol. 2003, 37 (18), 4182-4189.

(17) Stroud, J. L.; Norton, G. J.; Islam, M. R.; Dasgupta, T.; White, R. P.; Price, A. H.; Meharg, A. A.; McGrath, S. P.; Zhao, F. J. The dynamics of arsenic in four paddy fields in the Bengal delta. Environ. Pollut. 2011, 159 (4), 947-953.

(18) Inskeep, W. P.; Macur, R. E.; Hamamura, N.; Warelow, T. P.; Ward, S. A.; Santini, J. M. Detection, diversity and expression of aerobic bacterial arsenite oxidase genes. Environ. Microbiol. 2007, 9 (4), 934-943.

(19) Michel, C.; Jean, M.; Coulon, S.; Dictor, M. C.; Delorme, F.; Morin, D.; Garrido, F. Biofilms of As (III)-oxidising bacteria: Formation and activity studies for bioremediation process development. Appl. Environ. Microbiol. 2007, 77 (2), 457-467.

(20) Islam, F. S.; Gault, A. G.; Boothman, C.; Polya, D. A.; Charnock, J. M.; Chatterjee, D.; Lloyd, J. R. Role of metal-reducing bacteria in arsenic release from Bengal delta sediments. Nature 2004, 430 (6995), 68-71.

(21) Rhine, E. D.; Garcia-Dominguez, E.; Phelps, C. D.; Young, L. Environmental microbes can speciate and cycle arsenic. Environ. Sci. Technol. 2005, 39 (24), 9569-9573.

(22) Oremland, R. S.; Stolz, J. F. Arsenic, microbes and contaminated aquifers. Trends Microbiol. 2005, 13 (2), 45-49.

(23) Huang, H.; Jia, Y.; Sun, G. X.; Zhu, Y. G. Arsenic speciation and volatilization from flooded paddy soils amended with different organic matters. Environ. Sci. Technol. 2012, 46 (4), 2163-2168.

(24) Buée, M.; De Boer, W.; Martin, F.; Van Overbeek, L.; Jurkevitch, E. The rhizosphere zoo: An overview of plant-associated communities of microorganisms, including phages, bacteria, archaea, and fungi, and of some of their structuring factors. Plant Soil 2009, 321 (1), 189-212.

(25) Knief, C.; Delmotte, N.; Chaffron, S.; Stark, M.; Innerebner, G.; Wassmann, R.; von Mering, C.; Vorholt, J. A. Metaproteogenomic analysis of microbial communities in the phyllosphere and rhizosphere of rice. ISME J. 2011, 6, 1378-1390.

(26) Bais, H. P.; Weir, T. L.; Perry, L. G.; Gilroy, S.; Vivanco, J. M. The role of root exudates in rhizosphere interactions with plants and other organisms. Annu. Rev. Plant Biol. 2006, 57, 233-266.

(27) Jia, Y.; Huang, H.; Zhong, M.; Wang, F. H.; Zhang, L. M.; Zhu, Y. G. Microbial arsenic methylation in soil and rice rhizosphere. Environ. Sci. Technol. 2013, 47 (7), 3141-3148.

(28) Li, Y. L.; Fan, X. R.; Shen, Q. R. The relationship between rhizosphere nitrification and nitrogen-use efficiency in rice plants. Plant Cell Environ. 2008, 31 (1), 73-85.

(29) Jia, Y.; Sun, G. X.; Huang, H.; Zhu, Y. G. Biogas slurry application elevated arsenic accumulation in rice plant through increased arsenic release and methylation in paddy soil. Plant Soil 2012, 365, 387-396.

(30) Liu, W. J.; Zhu, Y. G.; Smith, F. A.; Smith, S. E. Do iron plaque and genotypes affect arsenate uptake and translocation by rice seedlings (Oryza sativa L.) grown in solution culture? J. Exp. Bot. 2004, 55 (403), 1707-1713.

(31) Sun, Y.; Polishchuk, E. A.; Radoja, U.; Cullen, W. R. Identification and quantification of ars $C$ genes in environmental samples by using real-time PCR. J. Microbiol. Meth. 2004, 58 (3), 335349.

(32) Kulp, T. R.; Hoeft, S. E.; Miller, L. G.; Saltikov, C.; Murphy, J. N.; Han, S.; Lanoil, B.; Oremland, R. S. Dissimilatory arsenate and sulfate reduction in sediments of two hypersaline, arsenic-rich soda lakes: Mono and Searles Lakes, California. Appl. Environ. Microbiol. 2006, 72 (10), 6514-6526.

(33) Xu, X. Y.; McGrath, S. P.; Meharg, A. A.; Zhao, F. J. Growing rice aerobically markedly decreases arsenic accumulation. Environ. Sci. Technol. 2008, 42 (15), 5574-5579.

(34) Hoeft, S. E.; Kulp, T. R.; Stolz, J. F.; Hollibaugh, J. T.; Oremland, R. S. Dissimilatory arsenate reduction with sulfide as electron donor: Experiments with mono lake water and isolation of strain MLMS-1, a chemoautotrophic arsenate respirer. Appl. Environ. Microbiol. 2004, 70 (5), 2741-2747.

(35) Macur, R. E.; Jackson, C. R.; Botero, L. M.; Mcdermott, T. R.; Inskeep, W. P. Bacterial populations associated with the oxidation and reduction of arsenic in an unsaturated soil. Environ. Sci. Technol. 2004, 38 (1), 104-111.

(36) Song, B.; Chyun, E.; Jaffe, P. R.; Ward, B. B. Molecular methods to detect and monitor dissimilatory arsenate-respiring bacteria (DARB) in sediments. FEMS Microbiol. Ecol. 2009, 68 (1), 108-117.

(37) Hery, M.; Van Dongen, B. E.; Gill, F.; Mondal, D.; Vaughan, D. J.; Pancost, R. D.; Polya, D. A.; Lloyd, J. R. Arsenic release and attenuation in low organic carbon aquifer sediments from West Bengal. Geobiology 2010, 8 (2), 155-168.

(38) Bhattacharjee, H.; Rosen, B. P. Arsenic Metabolism in Prokaryotic and Eukaryotic Microbes. In Molecular Microbiology of Heavy Metals; Nies, D. H., Silver, S., Eds.; Springer: Berlin, 2007; pp 371-406.

(39) Macur, R. E.; Wheeler, J. T.; McDermott, T. R.; Inskeep, W. P. Microbial populations associated with the reduction and enhanced mobilization of arsenic in mine tailings. Environ. Sci. Technol. 2001, 35 (18), 3676-3682.

(40) Bravin, M. N.; Travassac, F.; Le Floch, M.; Hinsinger, P.; Garnier, J. M. Oxygen input controls the spatial and temporal dynamics of arsenic at the surface of a flooded paddy soil and in the rhizosphere of lowland rice (Oryza sativa L.): A microcosm study. Plant Soil 2008, 312 (1), 207-218.

(41) Seyfferth, A. L.; Webb, S. M.; Andrews, J. C.; Fendorf, S. Arsenic localization, speciation, and co-occurrence with iron on rice (Oryza sativa L.) roots having variable Fe coatings. Environ. Sci. Technol. 2010, 44 (21), 8108-8113.

(42) Xu, X. Y.; McGrath, S. P.; Zhao, F. J. Rapid reduction of arsenate in the medium mediated by plant roots. New Phytol. 2007, 176 (3), 590-599.

(43) Osborne, T. H.; Jamieson, H. E.; Hudson-Edwards, K. A.; Nordstrom, D. K.; Walker, S. R.; Ward, S. A.; Santini, J. M. Microbial oxidation of arsenite in a subarctic environment: diversity of arsenite oxidase genes and identification of a psychrotolerant arsenite oxidiser. BMC Microbiol. 2010, 10 (1), 205.

(44) Quéméneur, M.; Heinrich-Salmeron, A.; Muller, D.; Lièvremont, D.; Jauzein, M.; Bertin, P. N.; Garrido, F.; Joulian, C. Diversity surveys and evolutionary relationships of aoxB genes in aerobic arsenite-oxidizing bacteria. Appl. Environ. Microbiol. 2008, 74 (14), 4567-4573.

(45) Hamamura, N.; Macur, R. E.; Korf, S.; Ackerman, G.; Taylor, W. P.; Kozubal, M.; Reysenbach, A. L.; Inskeep, W. P. Linking microbial oxidation of arsenic with detection and phylogenetic analysis of arsenite oxidase genes in diverse geothermal environments. Environ. Microbiol. 2009, 11 (2), 421-431.

(46) Zhao, F. J.; McGrath, S. P.; Meharg, A. A. Arsenic as a food chain contaminant: mechanisms of plant uptake and metabolism and mitigation strategies. Annu. Rev. Plant Biol. 2010, 61, 535-559.

(47) Wu, C.; Ye, Z. H.; Li, H.; Wu, S. C.; Deng, D.; Zhu, Y. G.; Wong, M. H. Do radial oxygen loss and external aeration affect iron plaque formation and arsenic accumulation and speciation in rice? $J$. Exp. Bot. 2012, 63 (8), 2961-2970.

(48) Wu, C.; Ye, Z. H.; Shu, W. S.; Zhu, Y. G.; Wong, M. H. Arsenic accumulation and speciation in rice are affected by root aeration and variation of genotypes. J. Exp. Bot. 2011, 62 (8), 2889-2898. 